\title{
Column
}

\section{Om de kwaliteit van de informatievoorziening}

\section{Luc van Zutphen}

Kwaliteit staat hoog genoteerd in onze maatschappij. En niet alleen als het gaat om water, lucht, roomboter en stofzuigers. Het kwaliteitsstreven is ook van grote betekenis in bedrijfsfuncties als inkoop, produktie, marketing en logistiek. En om wat dichterbij de eigen stiel te blijven, evenzeer voor professionele dienstverleners als accountants, organisatieadviseurs en fiscalisten. De laatste tijd heeft de kwaliteitscultus ook aanstekelijk gewerkt op het complexe veld van de informatievoorziening. Quality assurance in systeemontwikkelingsprocessen en certificatie van informatietechnologie zijn enkele voorbeelden. Een terechte aandacht, gezien de enorme impact van informatiesystemen op management en organisatie, de overheid en niet te vergeten de individuele burger.

$K$ waliteit is een moeilijk begrip. Het valt nog mee als kwaliteit in strikt technische zin wordt bezien. In normblad NEN 2646 bijvoorbeeld wordt kwaliteit omschreven als 'de mate waarin het geheel van eigenschappen van een produkt, proces of dienst voldoet aan de eraan gestelde eisen, welke voortvloeien uit het gebruiksdoel'.

Maar, geachte lezer, ook in deze beperkte zin kan er al verschil van interpretatie zijn. Echte westerlingen zoals Amerikanen spreken koel en feitelijk van 'conformity to specifications'. Voldoet de grasmaaier wel aan de technische specificaties van veiligheid, vormgeving en bedrijfszekerheid? Echte oosterlingen daarentegen, de Japanners kijken iets verder in de richting van de consument en spreken liever van 'fitness for use'. Nut, geschiktheid en toegevoegde waarde vanuit het standpunt van de gebruiker bepalen het kwaliteitscriterium. Zij menen daardoor dichterbij de consument en de markt te staan en ik denk dat ze daarin gelijk hebben.

Toegepast op informatievoorziening zou kwaliteit kunnen zijn de mate waarin het geheel van gedrags-en prestatiekenmerken van de informatiesystemen voldoet aan de door gebruiker eraan gestelde eisen. Of anders gezegd de mate waarin men zich kan verlaten op een informatiesysteem als primair of ondersteunend proces bij uitvoering, besluitvorming, communicatie, verantwoording, controle enzovoorts.

Maar nu wordt het kwaliteitsbegrip pas echt ingewikkeld want er kan niet meer gesproken worden van één of enkele kenmerken. Een zeer omvangrijke set van eisen op het gebied van snelheden, capaciteiten, volumes, responsetijden en dergelijke tot en met meer softe karakteristieken als bedienbaarheid, fraudebestendigheid en gebruikersvriendelijkheid is aan de orde.

Daar komt bij dat kwaliteit van de informatievoorziening in de eigen organisatorische en bestuurlijke, maar vooral ook personele context zal moeten worden ontwikkeld en beheerst. Informatievoorziening omvat immers technische, organisatorische en menselijke componenten.

Volmaakte kwaliteit is onbereikbaar en zo het al mogelijk was: onbetaalbaar. De relatie kwaliteit/ kosten zal altijd - en vaak een doorslaggevenderol spelen in het patroon van overwegingen. Kwaliteit van de informatievoorziening is geen statisch, geen te fixeren begrip. Kwaliteit moet worden gedefinieerd, genormeerd, ontwikkeld en opgevoerd; kortom beheerst. De eindverantwoordelijkheid hiervoor moet door managers worden gedragen, ook als het gaat om projecten, operationele systemen en rekencentra. Als het

Prof. L. C. van Zutphen, registeraccountant, is voorzitter van het Bestuurscollege van Deloitte Dijker Van Dien. Buitengewoon hoogleraar accountancy aan de Vrije Universiteit te Amsterdam. Lid van de Orde van Organisatiekundigen en -adviseurs. 
goed is zullen kwaliteit en kwaliteitsbeheersing de gehele organisatie doortrekken. Daartoe zal een reeks van managementtechnieken moeten worden ingezet.

Voor actieve en werkelijk effectieve kwaliteitsbeheersing op het gebied van de informatievoorziening is een kwaliteitsbeleid nodig dat niet in algemene bedoelingen blijt steken, maar als het ware tastbaar wordt door middel van operationele doelstellingen, normen, meet- en controlesystemen. Echter, deze reeks is gemakkelijker opgeschreven dan in de praktijk gerealiseerd! Managers, informatici en gebruikers zijn in de meeste bedrijven nog maar pas op weg als het gaat om geïntegreerde kwaliteitsbeheersing van informatieprocessen.

Wetenschappers en praktijkmensen kunnen hen daarbij helpen door publikaties en ervaringsuitwisseling.

Voor beiden biedt ons veelgelezen maandblad alle gelegenheid.

\section{Van de redactie}

De wijziging in het redactiebeleid, zoals aangekondigd in het eerste nummer van 1989, heeft er toe geleid dat de redactie is uitgebreid tot een redactieraad. De samenstelling van deze redactieraad is weergegeven in het colofon.

\section{FAS 96,}

\section{belastingen}

\section{naar de winst \\ in de}

\section{jaarrekening}

Prof. Drs. G. G. M. Bak

\section{Inleiding}

In december 1987 verscheen Statement of Financial Accounting Standards no. 96, kortweg FAS 96. Het was een gloednieuwe richtlijn van de Amerikaanse FASB met betrekking tot 'Accounting for Income Taxes'. Inmiddels heeft de FASB in december 1988 een vervolg gepubliceerd FAS 100 - waarin de ingangsdatum een jaar wordt verschoven. FAS 96 zal nu in de USA van toepassing zijn op jaarrekeningen over boekjaren die aanvangen na 15 december 1989. Deze ongebruikelijke stap was het gevolg van een stroom van klachten en protesten uit het bedrijfsleven. De regeling wordt als dermate gecompliceerd en betuttelend ervaren dat meer tijd nodig is ter voorbereiding op de toepassing ervan.

FAS 96 vervangt de bestaande regelgeving in de USA die nog was gebaseerd op de richtlijn (no. 11) van de Accounting Principles Board (APB), het orgaan dat tot 1973 de toon aangaf in 'standard setting' voor externe verslaggeving.

Ten opzichte van APB no. 11 maakt FAS 96 een belangrijke ommezwaai: van de 'deferred method' naar de 'assets and liabilities method'. In de deferred method vormt de (vennootschaps) belasting over het boekjaar de basis, gecorrigeerd voor (het belastingpercentage over) verschillen tussen jaarrekeningresultaat en fiscaal

Prof. Drs. G. G. M. Bak, registeraccountant, is vennoot van Deloitte Dijker Van Dien en Hoogleraar Accountancy aan de Katholieke Universiteit Brabant. 